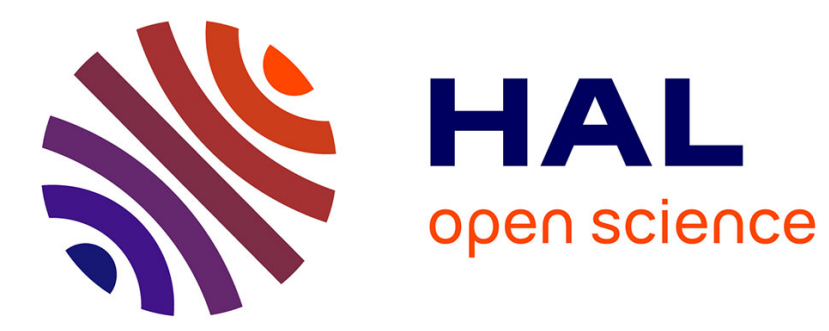

\title{
Newly discovered colour-pattern polymorphism of Bombus koreanus females (Hymenoptera: Apidae) demonstrated by DNA barcoding
}

Jiaxing Huang, Jie Wu, Jiandong An, Paul H. Williams

\section{To cite this version:}

Jiaxing Huang, Jie Wu, Jiandong An, Paul H. Williams. Newly discovered colour-pattern polymorphism of Bombus koreanus females (Hymenoptera: Apidae) demonstrated by DNA barcoding. Apidologie, 2015, 46 (2), pp.250-261. 10.1007/s13592-014-0319-9 . hal-01284442

HAL Id: hal-01284442

https://hal.science/hal-01284442

Submitted on 7 Mar 2016

HAL is a multi-disciplinary open access archive for the deposit and dissemination of scientific research documents, whether they are published or not. The documents may come from teaching and research institutions in France or abroad, or from public or private research centers.
L'archive ouverte pluridisciplinaire HAL, est destinée au dépôt et à la diffusion de documents scientifiques de niveau recherche, publiés ou non, émanant des établissements d'enseignement et de recherche français ou étrangers, des laboratoires publics ou privés. 


\title{
Newly discovered colour-pattern polymorphism of Bombus koreanus females (Hymenoptera: Apidae) demonstrated by DNA barcoding
}

\author{
Jiaxing HuANG ${ }^{1}$, Jie $\mathrm{Wu}^{1}$, Jiandong $\mathrm{AN}^{1}$, Paul H. WiLliams ${ }^{1,2}$ \\ ${ }^{1}$ Key Laboratory for Insect-Pollinator Biology of the Ministry of Agriculture, Institute of Apiculture, Chinese Academy \\ of Agricultural Sciences, No.1 Beigou, Xiangshan, Haidian District, Beijing 100093, China \\ ${ }^{2}$ Department of Life Sciences, Natural History Museum, London SW7 5BD, UK
}

Received 4 December 2013 - Revised 10 September 2014 - Accepted 18 September 2014

\begin{abstract}
Bombus (Megabombus) koreanus (Skorikov) is a long-tongued bumblebee that specialises in visiting deep flowers. To describe the distribution, colour-pattern variation and food plants of B. koreanus, we collected specimens and DNA cytochrome oxidase I (COI) barcodes were obtained. Bayesian phylogenetic analysis of barcodes for Megabombus species shows that B. koreanus is one of the more recently diverged species and the sister species to Bombus consobrinus. Our results show that specimens with previously unknown colour patterns also belong to $B$. koreanus. We describe nine different colour patterns for workers and three for queens, in which the hair of the thorax varies from black to orange-brown. However, there is a lack of covariation between COI and colourpattern variation. B. koreanus has been recorded to visit 11 species of food plants showing that $B$. koreanus is polylectic. Our results demonstrate that COI barcoding is an effective method for studying closely related taxa and for recognising species with variable colour patterns.
\end{abstract}

\section{Bombus koreanus / DNA barcoding / taxonomy / colour pattern}

\section{INTRODUCTION}

Bumblebees (genus Bombus Latreille) are important pollinators for many wild flowers and for economically important food crops (Velthuis and van Doorn 2006; Grixti et al. 2009; Hou et al. 2009). They are especially efficient pollinators for Leguminosae and Solanaceae, which benefit from their particular ability in buzz pollination. Since the 1980 s, bumblebees have been used commercially to pollinate tomatoes, eggplants and strawberries in greenhouses because of lower production costs, increased yields and improved fruit qualities (Ravestijn and Sande 1991; Abak et al.

Corresponding author: J. Wu, apis@vip.sina.com

Manuscript editor: Marina Meixner
1995; Dimou et al. 2008). In recent years, the decline and localised extinction of wild pollinators has raised concern in different continents (Williams 1982; Goulson et al. 2006; Colla and Packer 2008). Thus, understanding the distribution of bumblebee species and their habitat requirements has become a vital activity for their conservation, which depends on accurate species identification. Here, we seek to recognise an important pollinator species in Asia.

Species identification has been difficult in bumblebees because of the high variability of colour patterns within species, with high rates of colour-pattern evolution even exceeding those in mitochondrial genes (Hines and Williams 2012). In addition, colour patterns often converge among bumblebee species depending on geography and habitat (Williams 2007; Duennes et al. 2012; Lozier et al. 2013). This is made all the more 
difficult because there are few reliable detailed descriptions of the diagnostic morphological characters of Asian bumblebee species, particularly for those from China, which includes about half of the world's bumblebee species (Williams et al. 2010). Therefore, it is difficult to identify species reliably, especially without access to the type specimens. Consequently, individuals with new colour patterns are easily mistaken for new species.

$B$. koreanus is a medium-sized and longtongued bumblebee species that belongs to the subgenus Megabombus Dalla Torre (Williams 1998) with morphology similar to Bombus consobrinus Dahlbom. Until now, females of B. koreanus (Skorikov) are expected to have the hair of the thorax and of metasomal terga 1-3 black and that of terga 4-5 is expected to be ochre yellow. This dark colour pattern of B. koreanus was first described from specimens collected in Korea by Skorikov (1933) and has been reported from both Korea and China (Skorikov 1933; Tkalcu 1961; Kim and Ito 1987; Lee and Dumouchel 1999). Sakagami (1976) later compared the morphology of B. koreanus, $B$. hortorum (Linnaeus), B. argillaceus (Scopoli), B. consobrinus and B. yezoensis Matsumura in trying to distinguish these taxa in eastern Asia. Recently, B. koreanus has been reported in China from Jilin province by Ruan et al. (2007), while An et al. 2008, 2011, 2014 have reported it from Shanxi, Heilongjiang, Liaoning, Beijing, Shaanxi and Gansu. However, these authors were reporting the distribution of the species based on its typical dark colour pattern. Its distribution, food plants and colour-pattern polymorphism have not been investigated in detail before.

In recent years, with the development of molecular methods, it has become much easier and more reliable to estimate phylogenetic relationships and to identify species. Kawakita et al. (2004) estimated the phylogeny, historical biogeography and character evolution in bumblebees based on an analysis of three nuclear genes. Their study confirmed that $B$. koreanus belongs to the subgenus Megabombus and that it is the sister species to B. consobrinus . Cameron et al. (2007) analysed many more species using four nuclear genes and one mitochondrial gene to gain a similar but even more strongly supported result. However, these studies concentrated on the more distant relationships among taxa and used very few specimens within species to assess closer relationships near the rank of species. In contrast to the nuclear genes in these studies, cytochrome oxidase I (COI) barcodes are relatively fast evolving and consequently have become popular for species identification and for studying relationships near the rank of species. COI barcodes provide an easily obtained, reliable and cost-effective solution, especially for morphologically cryptic species (Hebert et al. 2003). Consequently, COI barcodes have been used to re-evaluate species, estimate phylogenetic relationships and clarify species complexes in Asian bumblebees (Williams et al. 2011, 2012a, b, 2013) and therefore should be appropriate to assess colour-pattern polymorphism within the subgenus Megabombus .

In this study, COI barcodes are used to explore colour-pattern polymorphism by estimating the phylogenetic relationships among samples of $B$. koreanus and its close relatives, which include the species $B$. consobrinus. The geographic distribution and food plants of $B$. koreanus are described from the new samples, published studies and museum collections. Thus, the results of this work contribute basic information that is essential to the conservation of $B$. koreanus in the wild and for its possible utilisation in crop pollination.

\section{MATERIALS AND METHODS}

\subsection{Materials}

Samples of bumblebees of the subgenus Megabombus were collected each year from 2005 to 2012, from July to September. The sample sites are in north, northeast and northwest China, which cover the distribution of B. koreanus in China expected from previous collections (Figure 1). Detailed information regarding the collection site name, date, elevation and location were recorded using a hand-held GPS (Garmin 60CS; Table I). At the same time, records and photographs of the food plants visited by B. koreanus were made. Specimens of bumblebees were pinned, labelled, dried and deposited in the Chinese Academy of Agricultural Sciences, Institute of Apiculture, Beijing, 


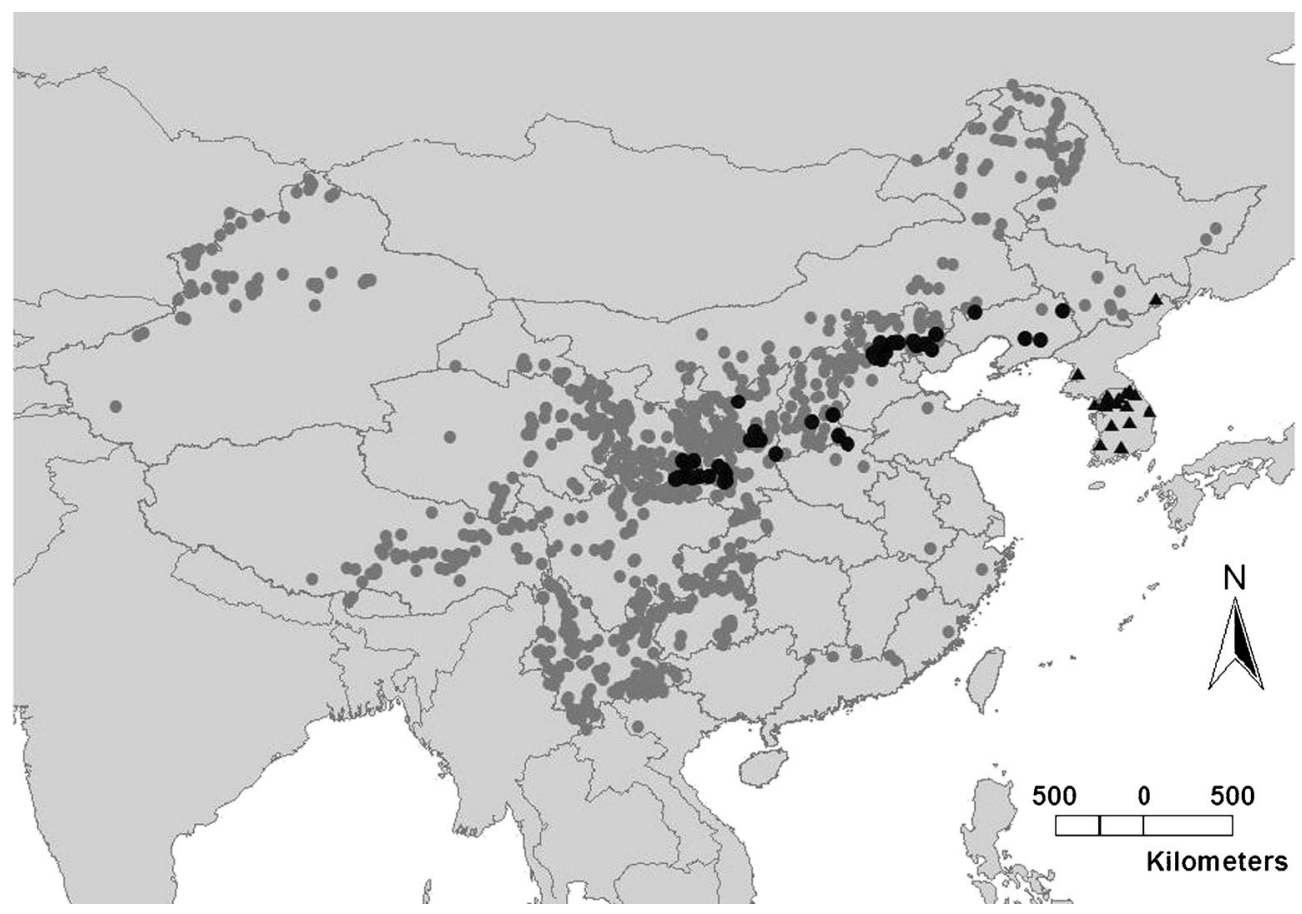

Figure 1. Distribution of B. koreanus based on specimen data from museum collections and literature records. Black spots show records of the $B$. koreanus specimens examined; black triangles show records of $B$. koreanus from the literature; and grey spots show records of all bumblebees in the IAB database.

China. Food plants were identified from photographs by Dr. Lei Meng of China Agricultural University, and all plant names were checked against the International Plant Names Index (http://www.ipni.org, accessed 2013).

Data were also compiled from the collections of the Natural History Museum, London; Institute of Zoology, Chinese Academy of Sciences, Beijing; and China Agricultural University, Beijing, China. Locality information was obtained from specimen labels and published studies or estimated from Google Earth (V7.1.2.2041, accessed 2013).

\subsection{Methods}

\subsubsection{DNA extraction}

Specimens with different colour patterns had DNA extracted from the right foreleg or midleg using Wizard SV 96 kit (Promega Inc.), with a slight modification for the protocol. Legs were ground in a $0.5-\mathrm{mL}$ Axygen tube in liquid nitrogen using a stainless steel pestle.
Thereafter, total DNA was extracted following the manufacturer's protocol.

\subsubsection{COI barcode sequence amplification}

For PCR amplification and sequencing of the short 5' barcode region of the mitochondrial COI gene, the universal insect primers LepF1 and LepR1 were used (Hebert et al. 2004). PCR amplification was carried out in $50 \mu \mathrm{L}$, including $25 \mu \mathrm{L}$ PCR Mix $(2 \times), 2 \mu \mathrm{L}$ primers $(10 \mu \mathrm{M})$ of each end and approximately $50 \mathrm{ng}$ of template DNA. The remaining volume was filled with $\mathrm{ddH}_{2} \mathrm{O}$. PCR amplification was done using the Eppendorf T-Gradient amplifier according to the following procedure: denaturation at $95{ }^{\circ} \mathrm{C}$ for $5 \mathrm{~min}$, followed by 35 cycles of $30 \mathrm{~s}$ at $95{ }^{\circ} \mathrm{C}, 30 \mathrm{~s}$ at $52{ }^{\circ} \mathrm{C}$, $60 \mathrm{~s}$ at $72{ }^{\circ} \mathrm{C}$ and a final extension at $72{ }^{\circ} \mathrm{C}$ for $10 \mathrm{~min}$. The amplified PCR product was then stored at $4{ }^{\circ} \mathrm{C}$ for further use. PCR products were checked under UV light after electrophoresis on a $1 \%$ agarose gel. Positive PCR products were sequenced from both ends by a commercial company (BioMed Beijing CO., LTD.). 


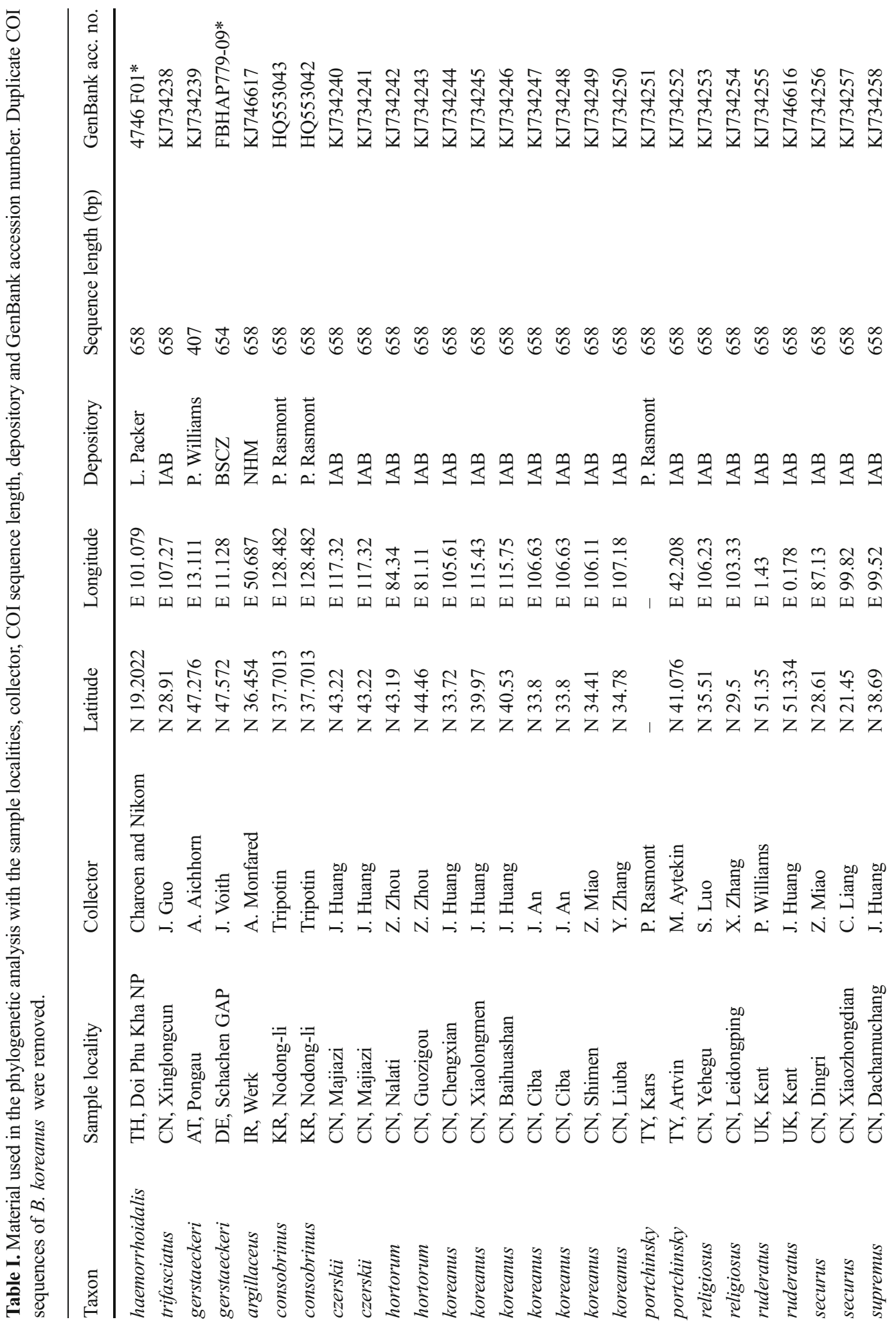




\subsubsection{Data analysis}

Sequences were examined using BioEdit (version v7.2.3; http://www.mbio.ncsu.edu/BioEdit/page2.html, accessed 2013), with which the primers were also removed from both ends (Table I). Sequences were aligned with the ClustalX2 program (version 2.0; Larkin et al. 2007). Nucleotide composition and informative sites were examined with MEGA software (version 5.1; Kimura 1980). The jModelTest (version 2.1.3) program was used to select the best nucleotide substitution model using the default parameters (Darriba, et al. 2012). The general time-reversible model with a gamma frequency distribution gave the best fit to our COI barcode dataset. We used B. haemorrhoidalis (Smith) and B. trifasciatus (Smith) as out-groups based on the results of Cameron et al. (2007). Phylogenetic relationships were estimated using the MrBayes software (version 3.2) (Ronquist et al. 2012). Two simultaneous analyses were performed using Markov Chain Monte Carlo (MCMC) simulations for 10 million generations with a sampling frequency of one in every 1000 generations. Burn-in was set to $10 \%$ of the generations, and the standard deviation of split frequencies was confirmed to be less than 0.01 (Darriba et al. 2012). Post burn-in sample trees from both replicates were combined and checked for convergence using Tracer (version 1.5.0; Rambaut 2007). The consensus tree was displayed and edited using FigTree software (version 1.4.0).

\section{RESULTS}

\subsection{COI barcode sequence analyses}

We found 510 conserved sites, 81 variable sites and 67 singleton sites in the Megabombus COI barcode sequences. All of the sequences were $658 \mathrm{bp}$ long after removing the primers from both ends. The average content of $\mathrm{A}, \mathrm{T}, \mathrm{G}$ and $\mathrm{C}$ was $31.9,44.6,13.1$ and $10.4 \%$, respectively. We found a strong $\mathrm{A}+\mathrm{T}$ bias in the COI barcode sequence, with an $\mathrm{A}+\mathrm{T}$ content of $76.5 \%$ compared to the $\mathrm{G}+\mathrm{C}$ content of $23.5 \%$. This bias supports the interpretation that all of the COI barcoding sequences came from mtDNA.

DNA was extracted and the COI barcode sequence was amplified successfully from 30 B. koreanus-like specimens, representing all of 
the new B. koreanus colour patterns. Among these sequences, we found seven unique haplotypes, with six polymorphic sites (Table II). Haplotype 1 was widespread among samples from Beijing, Shanxi, Shaanxi, Hebei and Gansu provinces. Haplotype 2 is a local type found only in Gansu, haplotypes 3 and 4 were found only in Beijing and haplotypes 5, 6 and 7 were found only in Shaanxi.

\subsection{Phylogeny of Megabombus}

Results of phylogenetic analysis (Figure 2) showed that most of the currently recognised species form groups with high posterior probabilities, strongly supporting the monophyly of these species. However, some deep nodes with posterior probabilities $<0.8$ are not well supported in our results. There is a strong support (posterior probability 1) for including many B. koreanus -like specimens that have the new extensively orange colour patterns within a single group, which is interpreted here as the species B. koreanus. Our results also support $B$. koreanus as the sister species to the paler, longer-haired species, B. consobrinus .

\subsection{Colour-pattern variation}

Simple diagrammatic coding to summarise the colour variation of $B$. koreanus shows that some specimens of $B$. koreanus are quite different in colour pattern from the type specimen (Figures 3 and 4 ). The colour variation detected among workers is much greater than among queens. The colour pattern of the hair of the workers' thorax varies from completely black to completely orange-brown (this pale pattern is similar to all males). In addition, some workers have extensive orange-brown hair on the metasoma. The previously described and common colour pattern of the hair of the thorax and of metasomal terga 1-3 is black and of terga 4-5 ochre is yellow. Figure 5 shows nine colour patterns of $B$. koreanus from Beijing, which is the highest number of colour patterns among all of the regions. There were many other slight variations in intermediate colour patterns among worker specimens from west Beijing. Most of them were collected from the transition zone between the Taihang Mountain and Yanshan mountains of north China, such as from Lingshan nature reserve, Xiaowutai nature reserve and Baihuashan nature reserve.

\subsection{Geographical distribution}

Our revised concept of $B$. koreanus, based on COI barcodes, is of a species more broadly distributed in Korea and China (Figure 1): it extends from northeastern China up to the edge of the east Tibetan Plateau in Central China, and through Liaoning, Hebei, Beijing, Shanxi, Henan, Shaanxi and Gansu Provinces. From our collections, B. koreanus has an elevation range of 500$2000 \mathrm{~m}$ (mean $1104 \mathrm{~m}$ ), with its greatest abundance in habitats from 1000 to $1500 \mathrm{~m}$. This pattern of elevational distribution is not affected substantially by latitude or longitude.

Table II. Haplotypes of the COI barcode sequence among B. koreanus samples.

\begin{tabular}{|c|c|c|c|c|c|c|}
\hline \multirow[t]{2}{*}{ Haplotypes } & \multicolumn{6}{|c|}{ Nucleotide position } \\
\hline & 25 & 88 & 199 & 235 & 500 & 565 \\
\hline B.koreanus 1 & $\mathrm{~A}$ & $\mathrm{~T}$ & $\mathrm{~A}$ & $\mathrm{~T}$ & $\mathrm{~T}$ & A \\
\hline B.koreanus 2 & G & $\mathrm{T}$ & $\mathrm{A}$ & $\mathrm{C}$ & $\mathrm{T}$ & A \\
\hline B.koreanus 3 & $\mathrm{~A}$ & $\mathrm{~T}$ & $\mathrm{~A}$ & $\mathrm{~T}$ & $\mathrm{C}$ & $\mathrm{A}$ \\
\hline B.koreanus 4 & $\mathrm{~A}$ & $\mathrm{~A}$ & A & $\mathrm{T}$ & $\mathrm{T}$ & $\mathrm{A}$ \\
\hline B.koreanus 5 & G & $\mathrm{T}$ & A & $\mathrm{T}$ & $\mathrm{T}$ & $\mathrm{A}$ \\
\hline B.koreanus 6 & A & $\mathrm{T}$ & G & $\mathrm{T}$ & $\mathrm{T}$ & A \\
\hline B.koreanus 7 & A & $\mathrm{T}$ & A & $\mathrm{T}$ & $\mathrm{T}$ & $\mathrm{G}$ \\
\hline
\end{tabular}




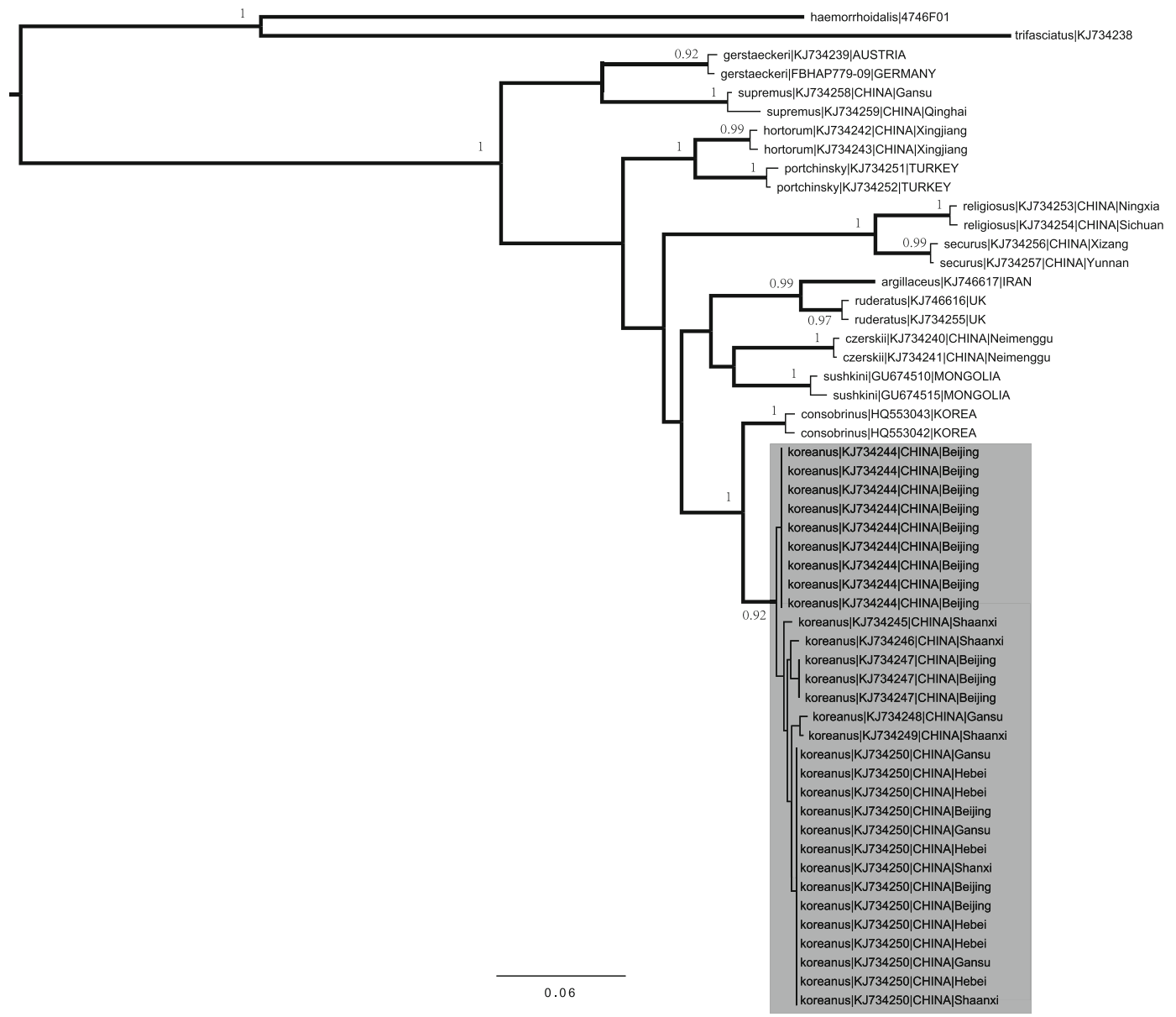

Figure 2. Estimate of the phylogenetic relationships within the subgenus Megabombus from COI barcode sequences by MrBayes. The numbers at nodes are the posterior probability support values. The grey box covers $B$. koreanus as recognised here. The scale bar represents 0.06 expected substitutions per nucleotide site.

\subsection{Forage plants}

B. koreanus is known to be a long-tongued bumblebee species that can collect nectar and pollen from many species of plants, making it polylectic. According to data for forage plants collected between 2005 and 2012 in China, this species is confirmed to visit 11 plant species (Cosmos bipinnatus Cav., Cirsium leo Nakai et Kitag.; Cucurbita moschata Duch., Cucumis sativus Linn.; Vicia cracca Linn.; Impatiens balsamina Linn.; Elsholtzia ciliate Hyland.; Leonurus sibiricus Linn.; Malva cathayensis $M$. G. Gilbert, Y. Tang et Dorr; Duchesnea indica Andr.; and Aconitum kusnezoffii Rchb.) belonging to eight plant families (Asteraceae, Cucurbitaceae, Fabaceae, Balsaminaceae, Lamiaceae, Malvaceae, Rosaceae and Ranunculaceae).

\section{DISCUSSION}

Multi-gene studies by Kawakita et al. (2004) and by Cameron et al. (2007) have made great progress in clarifying the relationships among bumblebee species, especially among the more distantly related species. Megabombus was shown to be a monophyletic group by both analyses. Our findings support the results of Cameron et al. (2007) 


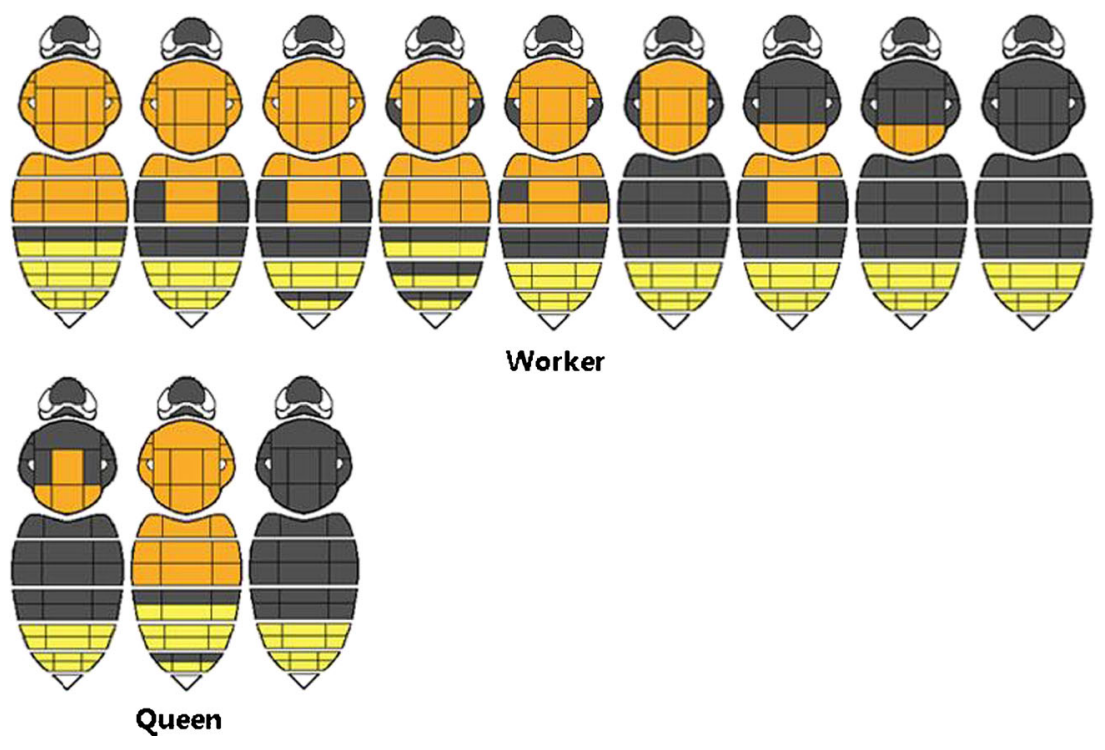

Figure 3. Diagrams summarising the principal colour patterns of the dorsal pubescence (hair) of B. koreanus; the dark patterns to the right are the most common.

that B. koreanus and B. consobrinus are sister species. But, as might be expected with a faster-evolving gene, our COI barcodes provide weak support for deeper and older groups, which are better supported by the slower evolving nuclear genes in the earlier studies.

Our results demonstrate that the species B. koreanus can be identified by COI barcodes and that it includes a broad range of previously unknown colour patterns with more or less extensive orange-brown hair in the females. This confirms the value of evidence from COI barcodes for studying the more closely related bumblebee species despite the variation within species (Carolan et al. 2012; Williams et al. Williams et al. 2012a, b). Previous authors had accepted (Skorikov 1933; Kim and Ito 1987) that $B$. koreanus females are all characterised by black hair on the face, thorax and metasomal terga 1-3 and ochre yellow on terga 4-5. Consequently, we have identified 10 new colour patterns of the hair for females (Figure 3: eight for workers and two for queens). This extends the known variation from completely black to completely orangebrown for the thorax and for metasomal tergum $1-3$. These pale females are similar to the pale colour patterns known previously from all males of B. koreanus .

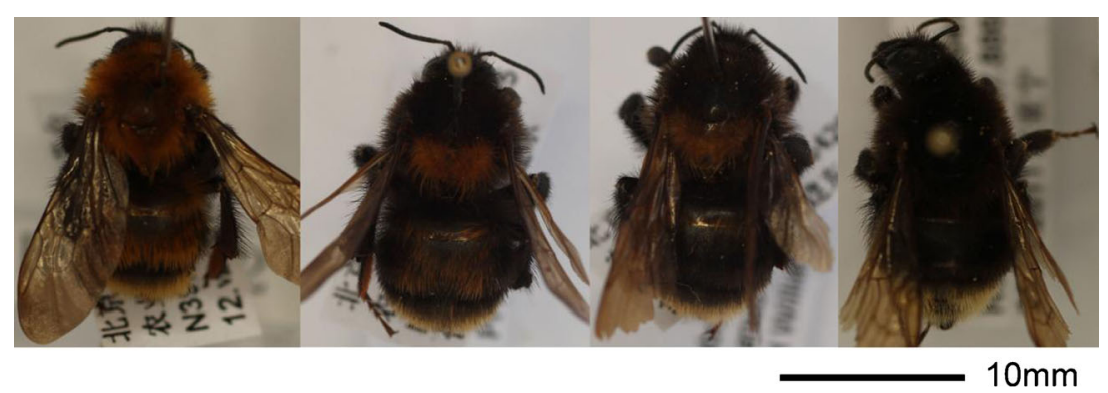

Figure 4. Photos show that different colour patterns of $B$. koreanus worker. The colour pattern of the type specimen is the hair of the thorax and of metasomal terga 1-3 black and terga 4-5 is ochre yellow (the rightmost photo). 


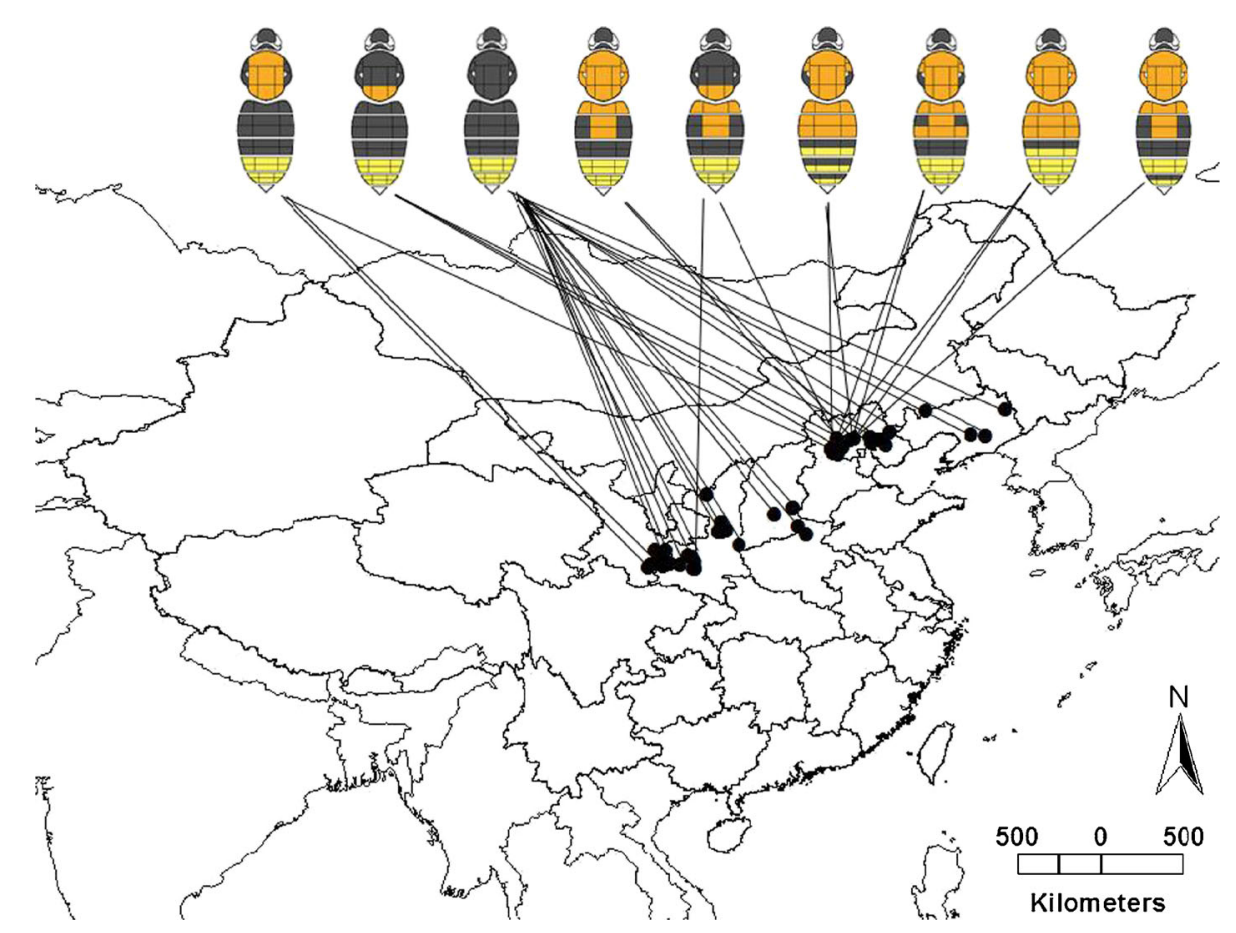

Figure 5. Map showing the distributions of the different colour patterns of $B$. koreanus among the samples obtained from China.

Substantial colour variation within bumblebee species recognised from morphology has been known for more than a century (Vogt 1909). Recent molecular studies have confirmed this interpretation (Duennes et al. 2012; Hines and Williams 2012; Williams et al. 2012a, b). Our results demonstrate that COI barcode haplotypes do not covary closely with the different colour patterns within $B$. koreanus in any simple way (Figure 6), suggesting that the two sets of characters are likely to be inherited independently. For the investigation of the variation of colour patterns, a better understanding of the genes controlling inheritance of colour-pattern components is needed.

Understanding the extent of polymorphism in the colour pattern of B. koreanus has extended our knowledge of the distribution of the species in China. We recognise that our COI barcode study has examined only specimens collected in recent years, although data from older museum collections and published references were used to compile the global distribution map (Figure 1).
Surveys are now being extended to look for this species in other areas of China (Williams et al. 2010).

Bumblebees of the subgenus Megabombus have the longest tongues among all bumblebees worldwide. These long-tongued bumblebees are known as important pollinators of plants with long corolla flowers (Brian 1957; Prys-Jones and Corbet 1987). Proboscis length could affect bumblebee community structure and species distributions (Williams 1988; Pellissier et al. 2013). Extremely long tongues are likely to have contributed to oligolecty in the sister species, B. consobrinus, at least in northern Europe and Russia (Løken 1973; Pekkarinen 1979; Mjelde 1983) although not in north China, where they can be polylectic (An et al. 2014). Our forage data here show that $B$. koreanus is also polylectic.

An improved understanding of $B$. koreanus improves our knowledge in two ways. First, colour pattern is an important character often used in bumblebee identification. The demonstration of the colour polymorphism will facilitate the correct 


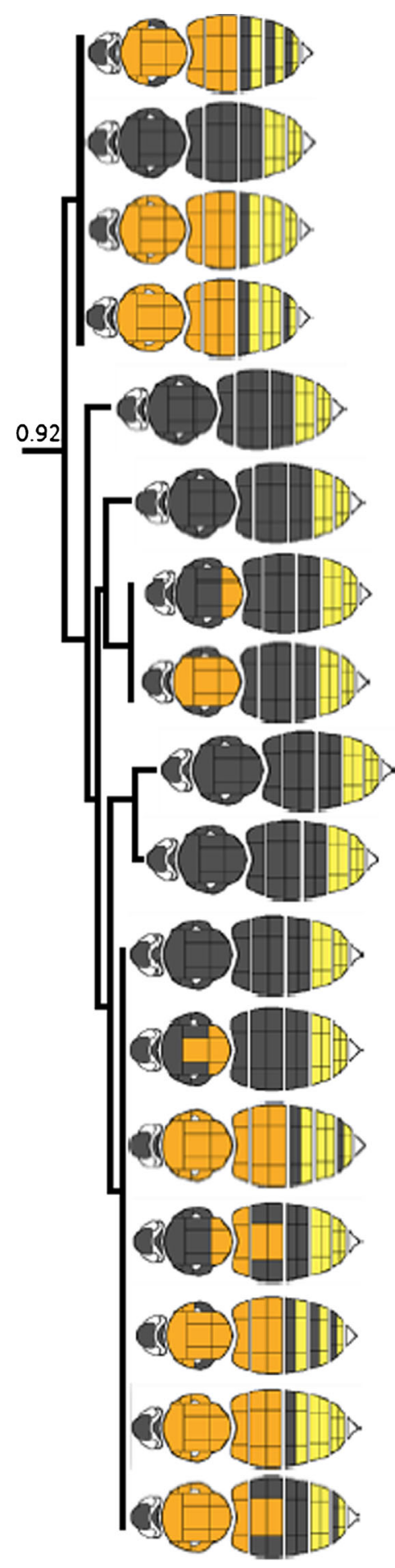

Figure 6. Colour patterns were assigned to the COI haplotype tree from MrBayes. Duplicate colour patterns from the same branch have been removed. identification of the species, contributing to assessing its current conservation status. Second, a better understanding of this long-tongued bee, its geographic distribution, and its foraging behaviour and food plants, and will help in exploring the evolution of specialisation among long-tongued bees, including its more specialised sister species, B. consobrinus .

\section{ACKNOWLEDGMENTS}

This work was supported financially by the China Agriculture Research System (CARS-45), the International Cooperation and Exchange Program between the Natural Science Foundation of China and the Royal Society UK (31211130110) and the Special Fund for Agro-scientific Research in the Public Interest (201203080). We thank P. Rasmont, M. Aytekin, L. Packer, J. Voith and A. Monfared for collecting specimens or providing COI barcodes. We thank Dr. Abebe Jenberie Wubie for his help in discussing the manuscript. We also thank two anonymous referees for their helpful comments in revising the manuscript.

Polymorphisme récemment découvert chez Bombus koreanus (Hymenoptera: Apidae), basé sur le dessin des couleurs des femelles et confirmé par le barcoding ADN

Bombus koreanus / taxonomie / barcode ADN / répartition des couleurs

Neu entdeckte Vielfalt der Farbvarianten in Weibchen von Bombus koreanus (Hymenoptera: Apidae) und Bestätigung durch DNA-Barcoding

Bombus koreanus / DNA barcoding / Taxonomie / Farbvariante

\section{REFERENCES}

Abak, K., Sari, N., Paksoy, M., et al. (1995) Efficiency of bumblebees on the yield and quality of eggplant and tomato grown in unheated glasshouses. Acta Hort. 412: 268-274.

An, J.D., Yao J., Huang, J.X. et al. (2008) Bombus fauna (Hymenoptera, Apidae) in Shanxi, China. Acta Zoot. Sinica 33 (01): 80-88.

An, J.D, Williams, P.H., Zhou, B., Miao Z.Y., Qi W.Z. (2011) The bumblebees of Gansu, Northwest China (Hymenoptera, Apidae). Zootaxa 2865 : 1-36. 
An, J.D, Huang, J.X., Shao, Y.Q., Zhang S.W., Wang B., Liu X.Y., Wu J., Williams P.H. (2014) The bumblebees of North China (Apidae, Bombus Latreille). Zootaxa 3830: 1-89.

Brian, A.D., (1957) Differences in the flowers visited by four species of bumble-bees and their causes. J. Anim. Ecol. 26(1): 71-98.

Cameron, S.A., Hines, H.M., Williams, P.H. (2007) A comprehensive phylogeny of the bumble bees (Bombus ). Biol. J. Linn. Soc. 91 : 161-188.

Carolan, J.C., Murray, T.E., Fitzpatrick, U., Crossley J., Schmidt H., Cederberg B., McNally L., Paxton R.J., Williams P.H., Brown M.J.F. (2012) Colour patterns do not diagnose species: quantitative evaluation of a DNA barcoded cryptic bumblebee complex. PLoSONE. 7 (1): e29251.

Colla, S.R., Packer, L. (2008) Evidence for decline in eastern North American bumblebees (Hymenoptera: Apidae), with special focus on Bombus affinis Cresson. Biodivers. Conserv. 17 (6): 1379-1391.

Darriba, D., Taboada, G.L., Doallo, R., Posada D. (2012) jModelTest 2: more models, new heuristics and parallel computing. Nat. Methods. 9 (8): 772.

Dimou, M., Taraza, S., Thrasyvoulou, A., Vasilakakis M. (2008) Effect of bumble bee pollination on greenhouse strawberry production. J. Apic. Res. 47 (2): 99-101.

Duennes, M.A., Lozier, J.D., Hines, H.M., Cameron S.A. (2012) Geographical patterns of genetic divergence in the widespread Mesoamerican bumble bee Bombus ephippiatus (Hymenoptera: Apidae). Mol. Phylogenet. Evol. 64 (1): 219-231.

Goulson, D., Hanley, M.E., Darvill, B., Ellis J.S. (2006) Biotope associations and the decline of bumblebees (Bombus spp.). J. Insect Conserv. 10(2): 95-103.

Grixti, J.C., Wong, L.T., Cameron, S.A., Favret, C. (2009) Decline of bumblebees (Bombus) in the North American Midwest. Biol. Conserv. 142 : 75-84.

Hebert, P.D., Cywinska, A., Ball, S.L., DeWaard J.R. (2003) Biological identifications through DNA barcodes. Proc. Biol. Sci. 270 (1512): 313-321.

Hebert, P.D.N., Penton, E.H., Burns, J.M., Janzen D.H., Hallwachs W. (2004) Ten species in one: DNA barcoding reveals cryptic species in the neotropical skipper butterfly Astraptes fulgerator. Proc Natl. Acad. Sci. Usa. 101 (41): 14812-14817.

Hines, H.M., Williams, P.H. (2012) Mimetic colour pattern evolution in the highly polymorphic Bombus trifasciatus (Hymenoptera: Apidae) species complex and its comimics. Zool. J. Linn. Soc.-Lond. 166 (4): $805-826$.

Hou, Q.Z., Duan, Y.W., Si, Q.W., et al. (2009) Pollination ecology of Gentiana Lawrencei Var. Farreri, A lateflowering Qinghai-Tibet Plateau Species. Chin. J. Plant Eco. (06):1156-1164.

Kawakita, A., Sota, T., Ito, M., Ascher J.S., Tanaka H., Kato M., Roubik D.W. (2004) Phylogeny, historical biogeography, and character evolution in bumblebees (Bombus : Apidae) based on simultaneous analysis of three nuclear gene sequences. Mol. Phylogenet. Evol. 31 (2): 799-804.

Kim, C.W., Ito, M. (1987) On the bumblebees from the Korean Peninsula (Hymenoptera, Bombidae). Entomol. Res. Bull. 13 : 1-41.

Kimura, M. (1980) A simple method for estimating evolutionary rates of base substitutions through comparative studies of nucleotide sequences. J. Mol. Evol. 16(2): 111-120.

Larkin, M.A., Blackshields, G., Brown, N.P., Chenna R., McGettigan P.A. et al. (2007) Clustal W and Clustal X version 2.0. Bioinformatics 23 (21): 2947-2948.

Lee, S., Dumouchel, L. (1999) Taxonomic Review of Genus Bombus (Hymenoptera, Apidae) from Korea. Insect Kore .16(1): 77-101.

Løken, A.,(1973) Studies on Scandinavian bumble bees (Hymenoptera, Apidae). Norsk entomologisk Tidsskrift. 20 (1): 1-218.

Lozier, J.D., Strange, J.P., Koch, J.B. (2013) Landscape heterogeneity predicts gene flow in a widespread polymorphic bumble bee, Bombus bifarius (Hymenoptera: Apidae). Conserv. Genet. 14(5): 1099-1110.

Mjelde, A. (1983) The foraging strategy of Bombus consobrinus (Hyemnoptera, Apidae). Acta Entomol. Fenn. 42 : 51-56.

Pekkarinen, A. (1979) Morphometric, colour and enzyme variation in bumblebees (Hymenoptera, Apidae, Bombus) in Fennoscandia and Denmark. Acta Zoolog. Fenn. 158: 1-60.

Pellissier, L., Pradervand, J., Williams, P.H., Litsios G., Cherix D., Guisan A. (2013) Phylogenetic relatedness and proboscis length contribute to structuring bumblebee communities in the extremes of abiotic and biotic gradients. Global. Ecol. Biogeogr. In Press.

Prys-Jones, O.E., Corbet S.A., (1987) Bumblebees. Cambridge: Cambridge University Press, $86 \mathrm{p}$.

Rambaut, A.D.A. (2007) Tracer v1.4: MCMC trace analyses tool [on line]. http://tree.bio.ed.ac.uk/software/tracer/ (accessed on 13 November 17).

Ravestijn, W.V., Sande, J.V.D. (1991) Use of bumblebees for the pollination of glasshouse tomatoes. Acta Hort.288 : 204-212.

Ronquist, F., Teslenko, M., van der Mark, P., Ayres D.L., Darling A., Hohna S., Larget B., Liu L., Suchard M.A., Huelsenbeck J.P. (2012) MrBayes 3.2: efficient Bayesian phylogenetic inference and model choice across a large model space. Syst. Biol. 61 (3): 539-542.

Ruan, C.C., Sun, G.Z., Zhang, J.J. (2007) Investigation on the Resources of Bombus in Jilin Province J. Jilin Agri. Univ. 27 (01): 47.

Sakagami, S.F. (1976) Some bumblebees from Korea with remarks on the Japanese fauna (Hymenoptera, Apidae). Annales Historico-Naturales Musei Nationalis Hungarici 67 : 293-316.

Skorikov, A. S. (1933) Zur Hummelfauna Japans und seiner Nachbarländer. Mushi 6(2): 53-65. 
Tkalcu, B. (1961) Zwei chinesische Hummel-Arten (Hymenoptera, Bombinae). Casopis Ceskoslovenské spolecnosti entomologické 58: 45-59.

Velthuis, H., van Doorn, A. (2006) A century of advances in bumblebee domestication and the economic and environmental aspects of its commercialization for pollination. Apidologie. 37 (4): 421-451.

Vogt, O. (1909) Studien über das Artproblem. 1. Mitteilung. Über das Variieren der Hummeln. 1. Teil. Sitzungsberichte der Gesellschaft naturforschender Freunde zu Berlin. 28-84.

Williams, P.H. (1982) The distribution and decline of British bumble bees (Bombus Latr.). J. Apic. Res. 21 : 236-245.

Williams, P.H. (1988) Habitat use by bumblebe bees (Bombus spp.). Ecol. Entomol. 13 : 223-237.

Williams, P.H. (1998) An annotated checklist of bumble bees with an analysis of patterns of description (Hymenoptera: Apidae, Bombini). Bull. Nat. Hist. Mus. Lond.(Ent.). 67 : 79-152.

Williams, P.H. (2007) The distribution of bumblebee colour patterns world-wide: possible significance for thermoregulation, crypsis, and warning mimicry. Biol. J. Linn. Soc. 92 : 97-118.

Williams, P.H., An, J., Huang, J., Yao J.A. (2010) BBCI: A new initiative to document Chinese bumble bees for pollination research. J. Apic. Res. 49 (2): 221-222.

Williams, P.H., An, J., Huang, J. (2011) The bumblebees of the subgenus Subterraneobombus: integrating evidence from morphology and DNA barcodes (Hymenoptera, Apidae, Bombus). Zool. J. Linn. Soc.-Lond. 163 (3): 813-862.

Williams, P.H., An, J., Brown, M.J.F., Carolan J.C., Goulson D., Huang J.X., Ito M. (2012) Cryptic Bumblebee Species: Consequences for Conservation and the Trade in Greenhouse Pollinators. PLoSONE. 7 (3): e32992.

Williams, P.H., Brown, M.J.F., Carolan, J.C., An J.D., Goulson D. et al. (2012) Unveiling cryptic species of the bumblebee subgenus Bombus s.str. worldwide with COI barcodes (Hymenoptera: Apidae). Syst. Biodiv. 10 : 1-36.

Williams, P.H., Byvaltsev, A., Sheffield, C., Rasmont P. (2013) Bombus cullumanus - an extinct European bumblebee species? Apidologie 44 (2): 121-132. 